\title{
Phosphorylation of Histone H2AX in the Mouse Brain from Development to Senescence
}

\author{
Serena Barral ${ }^{1, \dagger}$, Riccardo Beltramo ${ }^{1, \S}$, Chiara Salio ${ }^{1, \dagger}$, Patrizia Aimar ${ }^{1, \dagger}$, Laura Lossi ${ }^{1,2, *}$ and \\ Adalberto Merighi ${ }^{1,2, *}$
}

1 Department of Veterinary Sciences, Università di Torino, Via Leonardo da Vinci 44, Grugliasco I-10095, Italy; E-Mails: chiara.salio@unito.it (C.S.); patrizia.aimar@unito.it (P.A.)

2 Istituto Italiano di Neuroscienze (INN), Via Leonardo da Vinci 44, Grugliasco I-10095, Italy

* Present address: Miltenyi Biotec GmbH, Bergisch Gladbach 51427, Germany; E-Mail: serenab@miltenyibiotec.de.

$\S$ Present address: Istituto Italiano di Tecnologia (IIT), Genoa 16121, Italy; E-Mail: riccardo.beltramo@iit.it.

$\dagger$ These authors contributed equally to this work.

* Authors to whom correspondence should be addressed; E-Mails: laura.lossi@unito.it (L.L.); adalberto.merighi@unito.it (A.M.); Tel.: +39-011-670-9116 (L.L.); +39-011-670-9118 (A.M.); Fax: +39-011-670-9138 (L.L.); +39-011-236-9118 (A.M.).

Received: 12 November 2013; in revised form: 30 December 2013 / Accepted: 10 January 2014 / Published: 21 January 2014

\begin{abstract}
Phosphorylation of the histone $\mathrm{H} 2 \mathrm{AX}(\gamma \mathrm{H} 2 \mathrm{AX}$ form) is an early response to DNA damage and a marker of aging and disease in several cells and tissues outside the nervous system. Little is known about in vivo phosphorylation of $\mathrm{H} 2 \mathrm{AX}$ in neurons, although it was suggested that $\gamma \mathrm{H} 2 \mathrm{AX}$ is an early marker of neuronal endangerment thus opening the possibility to target it as a neuroprotective strategy. After experimental labeling of DNA-synthesizing cells with 5-bromo-2-deoxyuridine (BrdU), we studied the brain occurrence of $\gamma \mathrm{H} 2 \mathrm{AX}$ in developing, postnatal, adult and senescent ( 2 years) mice by light and electron microscopic immunocytochemistry and Western blotting. Focal and/or diffuse $\gamma \mathrm{H} 2 \mathrm{AX}$ immunostaining appears in interkinetic nuclei, mitotic chromosomes, and apoptotic nuclei. Immunoreactivity is mainly associated with neurogenetic areas, i.e., the subventricular zone (SVZ) of telencephalon, the cerebellar cortex, and, albeit to a much lesser extent, the subgranular zone of the hippocampal dentate gyrus. In addition, $\gamma \mathrm{H} 2 \mathrm{AX}$
\end{abstract}


is highly expressed in the adult and senescent cerebral cortex, particularly the piriform cortex. Double labeling experiments demonstrate that $\gamma \mathrm{H} 2 \mathrm{AX}$ in neurogenetic brain areas is temporally and functionally related to proliferation and apoptosis of neuronal precursors, i.e., the type $\mathrm{C}$ transit amplifying cells (SVZ) and the granule cell precursors (cerebellum). Conversely, $\gamma \mathrm{H} 2 \mathrm{AX}$-immunoreactive cortical neurons incorporating the $\mathrm{S}$ phase-label BrdU do not express the proliferation marker phosphorylated histone $\mathrm{H} 3$, indicating that these postmitotic cells undergo a significant DNA damage response. Our study paves the way for a better comprehension of the role of H2AX phosphorylation in the normal brain, and offers additional data to design novel strategies for the protection of neuronal precursors and mature neurons in central nervous system (CNS) degenerative diseases.

Keywords: H2AX; histone; DNA damage; immunocytochemistry; cell proliferation; apoptosis; neuroprotection; Alzheimer's disease; Huntington's disease

\section{Introduction}

First identified as an isoform of the core histone H2A, H2AX constitutes a major H2A species [1]. The role of $\mathrm{H} 2 \mathrm{AX} \gamma$-phosphorylation in DNA damage was first suggested by showing that phosphorylated $\mathrm{H} 2 \mathrm{AX}(\gamma \mathrm{H} 2 \mathrm{AX})$ appeared rapidly following cell exposure to ionizing radiations [1]. The amount of $\gamma \mathrm{H} 2 \mathrm{AX}$ was estimated to be directly related to the number of double strand breaks (DSBs) and, thus, to the extent of DNA damage [2]. In parallel, the development of specific anti- $\gamma \mathrm{H} 2 \mathrm{AX}$ antibodies confirmed that $\mathrm{H} 2 \mathrm{AX}$ was massively phosphorylated in nuclear foci of chromatin surrounding the DSBs [2]. Because of the rapid induction and amplification of $\gamma \mathrm{H} 2 \mathrm{AX}$, the existence of a dose-related linear increase of foci following exposure to irradiation [3], and the 1:1 correspondence between the number of $\gamma \mathrm{H} 2 \mathrm{AX}$ foci and the number of DSBs [4], $\gamma \mathrm{H} 2 \mathrm{AX}$ recognizing antibodies became the "gold standard" to histologically detect DSBs. Since these earlier observations, it became clear that $\gamma \mathrm{H} 2 \mathrm{AX}$ not only was related to the DNA damage that follows irradiation, but was also associated with senescence and disease in several cells, tissues and organs. In a seminal paper [5], senescing human cells of various origins (normal and WI38 fibroblasts, PrEC: prostate epithelial cells) and five mouse organs (liver, testis, kidney, lung and brain) were shown to display increased levels of $\mathrm{H} 2 \mathrm{AX}$ phosphorylation. These observations were subsequently, confirmed and/or extended [6-9], and, in parallel, $\gamma \mathrm{H} 2 \mathrm{AX}$ was described in various types of tumors entering the scene of clinical research and therapy in oncology $[10,11]$.

Whereas phosphorylation of $\mathrm{H} 2 \mathrm{AX}$ was extensively studied in connection with experimental DNA damage, senescence, and oncogenesis, comparatively little attention has been paid to $\gamma \mathrm{H} 2 \mathrm{AX}$ in normal cells, although it was originally reported that $\gamma \mathrm{H} 2 \mathrm{AX}$ levels change throughout cell cycle progression in proliferating HeLa cells with an intact DNA [12]. Later, it was concluded that phosphorylation of $\mathrm{H} 2 \mathrm{AX}$ assumed the form of a $\gamma \mathrm{H} 2 \mathrm{AX}$ focus only in response to DNA DSBs [3]. However, there were several cases of $\gamma \mathrm{H} 2 \mathrm{AX}$ formation not due to DSBs, although in these cases $\gamma \mathrm{H} 2 \mathrm{AX}$ did not assume a focal pattern [10]. Moreover, while at the beginning it was foci disappearance which was associated with the repair of DNA damage, $\gamma \mathrm{H} 2 \mathrm{AX}$ is now also used as a marker for 
exploring the spatial distribution and the cellular DNA repair kinetics $[3,13,14]$. Therefore, phosphorylation of H2AX not only is nowadays linked to a DNA damage response (DDR), but also to other yet uncharacterized functions, primarily during cell division and/or apoptosis.

Morphogenesis and cellular differentiation in central nervous system (CNS) take place very early in development. Although there are some remarkable exceptions including the possibility of a replacement in adult life [15], the vast majority of mature neurons is postmitotic, and lacks the capacity of proliferation. As a consequence, neurons in any species, at any given time, are virtually as old as the animal itself. Neurons are among the most metabolically active cells, their gene expression levels being two to three fold higher compared with other cell types [16]. This renders the brain one of the most vulnerable organs in terms of the damage to cellular DNA. Consequently, DDR and repair systems should have great importance not only during development, but also in the adult and old CNS.

Coincident with DNA repair is the activation of a DNA damage-induced signaling pathway that halts the cell cycle while repair occurs, or, alternatively, leads to apoptosis when damage is so extensive as to be incompatible with recovery [17]. Insults not necessarily resulting in neuronal death can induce $\gamma \mathrm{H} 2 \mathrm{AX}$, and a role for $\mathrm{H} 2 \mathrm{AX}$ alterations in determining neuronal vulnerability following damage was hypothesized. Not only did these observations suggest a different sensitivity to irradiation between neuronal precursors and mature neurons [18], but $\gamma \mathrm{H} 2 \mathrm{AX}$ was also proposed as an early marker of neuronal endangerment after ionotropic glutamate receptor activation and seizures in the adult brain $[19,20]$. In addition, DDR and H2AX phosphorylation have been implicated, albeit only tentatively, in Alzheimer's [21] and Huntington's [22] diseases. Altogether, these findings suggest that novel neuroprotective strategies could stem from specific targeting of the DDR/ $\gamma \mathrm{H} 2 \mathrm{AX}$ pathway.

We set up this study to map the occurrence of $\gamma \mathrm{H} 2 \mathrm{AX}$ in normal mouse brain. We asked whether or not there was a histological and structural relationship between $\mathrm{H} 2 \mathrm{AX}$ phosphorylation and the known sites of proliferation/apoptosis during the course of neural development and aging. We were convinced that an answer to the above question could be of help in setting a baseline for further exploitation of neuroprotective strategies tagging $\mathrm{H} 2 \mathrm{AX}$.

\section{Results and Discussion}

\subsection{Expression of $\gamma H 2 A X$ in the Mouse Brain}

A map of the occurrence and distribution of $\gamma \mathrm{H} 2 \mathrm{AX}$ was obtained in developing, postnatal, adult, and senescent mice along the entire rostro-caudal axis of the brain by coronal serial sectioning and immunocytochemistry (ICC) at light microscopy level using two different antibodies raised against H2AX phosphorylated at Ser139. Results of semi-quantitative analysis of distributional data are summarized in Figure 1 and Table 1.

The specificity of immunostaining was confirmed with current ICC controls and by detection of $\gamma \mathrm{H} 2 \mathrm{AX}$ in whole brain homogenates, after immunoprecipitation and Western blot analysis (Figure 2A). 
Figure 1. Maps of distribution of $\gamma \mathrm{H} 2 \mathrm{AX}$ immunoreactivity (IR) in forebrain. Coronal sections of the mouse brain (adapted from [23]). Red dots indicate the localization of immunoreactive nuclei. Abbreviations: $\mathrm{Au} 1=$ primary auditory cortex; $\mathrm{AuD}=$ second auditory cortex, dorsal; $\mathrm{AuV}=$ second auditory cortex, ventral; $\mathrm{CPu}=$ caudate nucleus/putamen; DG = dentate gyrus of hippocampus; EPl = external plexiform layer of the olfactory bulb; gcc = genu, corpus callosum; $\mathrm{GrO}=$ granule cell layer of the olfactory bulb; IPI = internal plexiform layer of the olfactory bulb; LSI = intermediate part of the lateral septal nucleus; $\mathrm{M} 1=$ primary motor cortex; $\mathrm{M} 2$ = second motor cortex; $\mathrm{Pir}=$ piriform cortex; $\mathrm{Mi}=$ mitral cell layer of the olfactory bulb; $\mathrm{S} 1=$ primary somatosensory cortex; S1BF = primary somatosensory cortex, barrel field; $\mathrm{S} 2$ = second somatosensory cortex; V1 = primary visual cortex; V2L = secondary visual cortex, lateral area; $\mathrm{V} 2 \mathrm{ML}=$ secondary visual cortex, mediolateral area; and $\mathrm{V} 2 \mathrm{MM}=$ secondary visual cortex, mediomedial area.

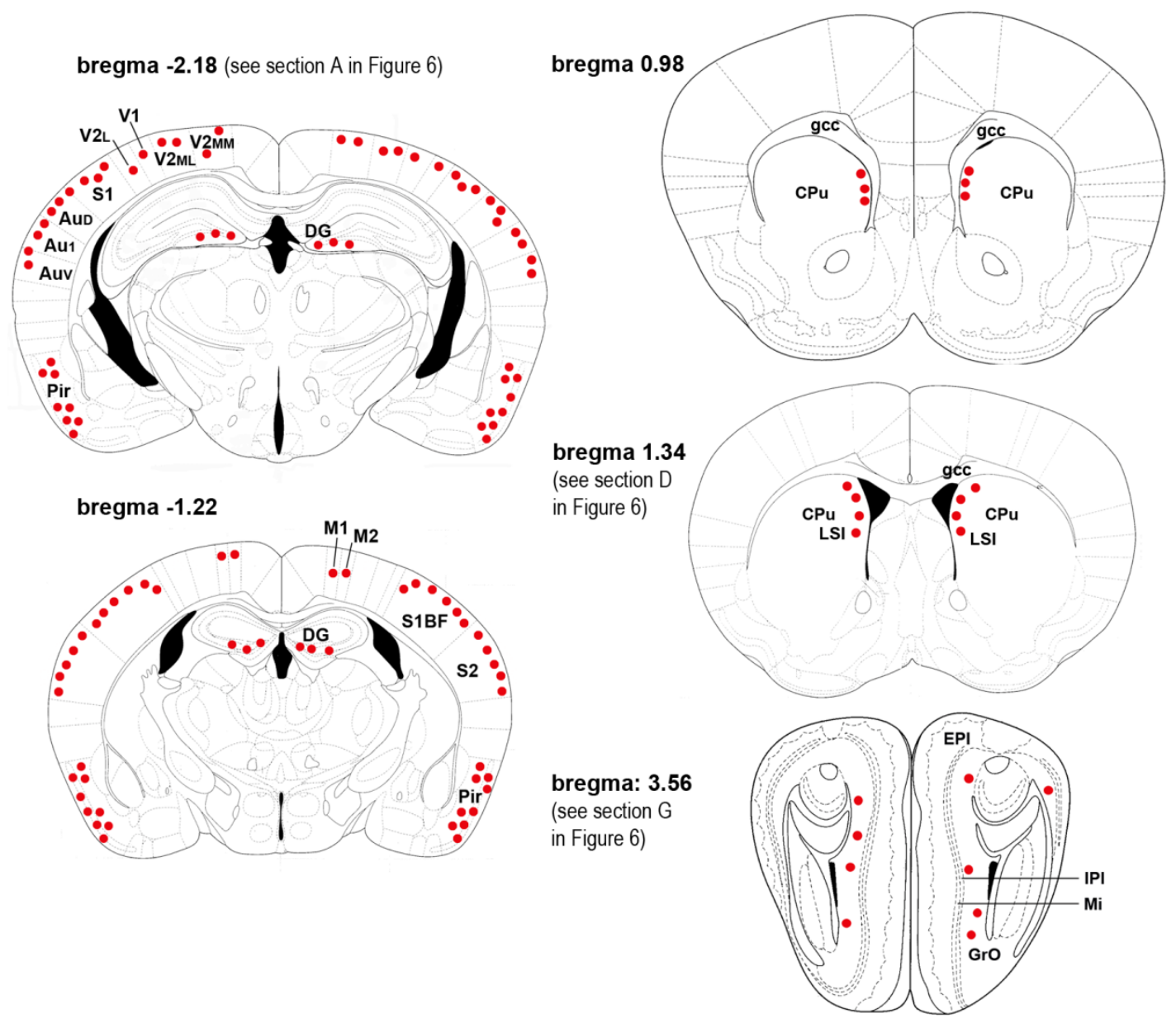

\subsubsection{Forebrain}

In the cerebral cortex, focal $\gamma \mathrm{H} 2 \mathrm{AX}-\mathrm{IR}$ was seen in mice older than P15 (Figure 2B-G). The strongest immunocytochemical signal was detected in layer II of the piriform cortex (Figures 2B,D,E and 3I), where labeled nuclei showed high numbers of well defined foci (Figure 2B lower insert). IR was evident also in somatosensory (Figure $2 \mathrm{C}$ ) and auditory (Figure 2F) cortex. $\gamma \mathrm{H} 2 \mathrm{AX}-\mathrm{IR}$ was mainly seen in neurons, but also in astrocytes (Figure $2 \mathrm{E}-\mathrm{G}$ ). 
Table 1. Semi-quantitative distribution of $\gamma \mathrm{H} 2 \mathrm{AX}-\mathrm{IR}$ nuclei in the mouse brain. Staining was performed on paraffin sections using the ABC method. The level of immunoreactivity (IR) through the brain was assessed using the following scale: - = no signal; + = weak staining; $++=$ moderate staining; $+++=$ strong staining. Abbreviations: $\gamma \mathrm{H} 2 \mathrm{AX}=$ phosphorylated form of histone $\mathrm{H} 2 \mathrm{AX} ; \mathrm{E}=$ embryonic day; $\mathrm{OB}=$ olfactory bulb; $\mathrm{P}=$ postnatal day; $\mathrm{RMS}=$ rostral migratory stream; and SVZ = subventricular zone.

\begin{tabular}{|c|c|c|c|c|c|c|c|c|}
\hline \multicolumn{9}{|c|}{ Distribution of $\gamma \mathrm{H} 2 \mathrm{AX}$-IR nuclei in mouse brain } \\
\hline Age & E 14.5 & $\mathrm{P} 0$ & P5 & $\mathrm{P} 10$ & $\mathrm{P} 15$ & $\mathrm{P} 20$ & P60 & Old \\
\hline \multicolumn{9}{|l|}{ Forebrain } \\
\hline Cerebral cortex & - & - & - & - & + & ++ & +++ & +++ \\
\hline SVZ/RMS/OB & +++ & + & + & +++ & ++ & ++ & ++ & ++ \\
\hline Amygdala & - & - & - & - & + & + & ++ & - \\
\hline Hypothalamus & - & - & - & - & - & + & ++ & - \\
\hline Dorsal endopiriform nucleus & - & - & - & + & - & + & + & - \\
\hline Hippocampus & - & . & - & + & + & + & + & - \\
\hline Midbrain & - & & - & - & + & + & + & - \\
\hline \multicolumn{9}{|l|}{ Hindbrain } \\
\hline Cerebellum & - & + & +++ & +++ & + & - & - & - \\
\hline Pons & - & - & - & - & + & + & + & + \\
\hline
\end{tabular}

Figure 2. Distribution of $\gamma \mathrm{H} 2 \mathrm{AX}$ mouse brain. (A) Western blot detection of $\gamma \mathrm{H} 2 \mathrm{AX}-\mathrm{IR}$ in immunoprecipitates of mouse whole brain extracts; (B-D) $\gamma \mathrm{H} 2 \mathrm{AX}$ IR in the cerebral cortex. Immunostaining displays a nuclear distribution in foci of intense IR (arrows-lower insert in (B)) or staining in metaphase chromosomes (arrowhead-upper insert in (B)). Four nuclei in (B) are encircled by red dots to respectively show, by way of examples, unstained, weakly, moderately, and strongly stained cells; (E) Double immunocytochemical labeling for $\gamma \mathrm{H} 2 \mathrm{AX}$ (red) and the neuronal marker NeuN (green). most nuclei in piriform cortex are double-labeled (yellow); and (F,G) Double immunocytochemical labeling for $\gamma \mathrm{H} 2 \mathrm{AX}$ (red) and GFAP (green): double-labeled astrocytes (yellow) in the auditory (the arrow in (F)) and primary visual cortex $(\mathbf{G})$ are apparent together with $\gamma \mathrm{H} 2 \mathrm{AX}$ (red) singularly labeled neuronal nuclei. Abbreviations: $\gamma \mathrm{H} 2 \mathrm{AX}=$ phosphorylated form of histone $\mathrm{H} 2 \mathrm{AX}$; Aud1 = primary auditory cortex; GFAP = glial fibrillary acidic protein; NeuN $=$ Neuronal nuclei antigen; $\mathrm{P}=$ postnatal day; $\mathrm{Pir}=$ piriform cortex; $\mathrm{S} 1=$ primary somatosensory cortex; and V1 = primary visual cortex. Scale bars: $50 \mu \mathrm{m}$; inserts: $10 \mu \mathrm{m}$.

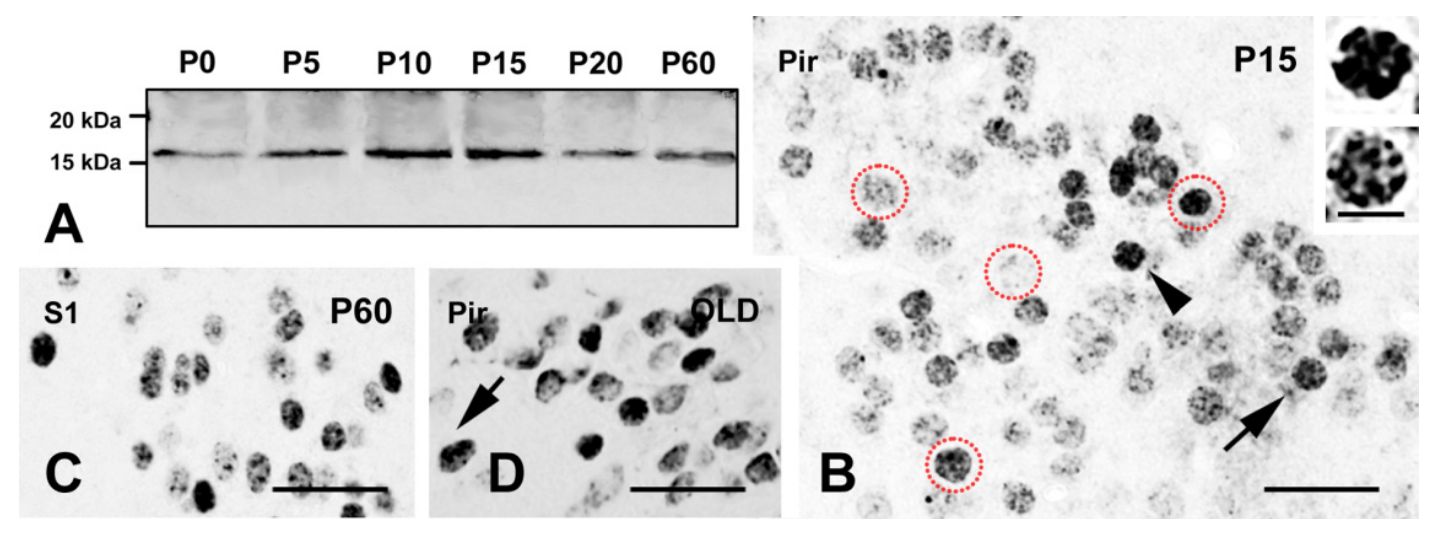


Figure 2. Cont.
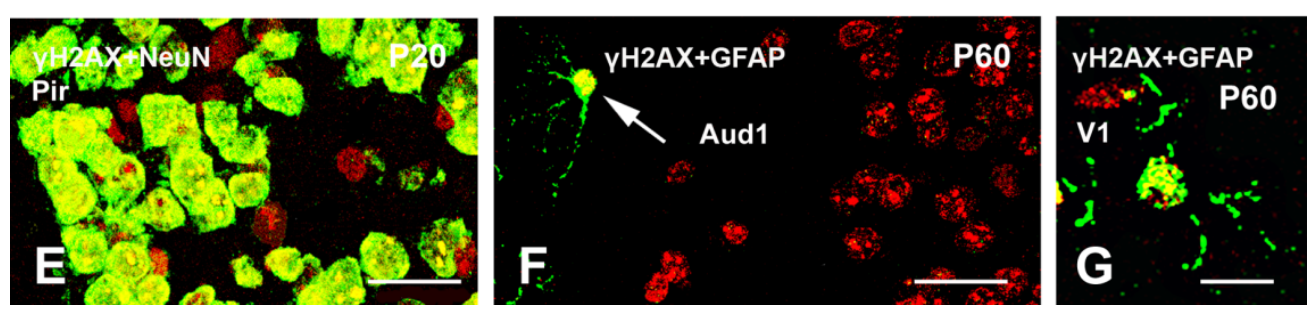

In the hippocampus, staining was observed in the subgranular zone of the dentate gyrus at P10-60. In the subventricular zone (SVZ), rostral migratory stream (RMS) and olfactory bulb (OB), $\gamma \mathrm{H} 2 \mathrm{AX}$-positive nuclei were interkinetic, mitotic or, far less frequently, apoptotic. In the wall of the third ventricle, strongest labeling was detected in E 14.5 embryos (Figure 3A); immunoreactivity then declined at birth, but increased again to reach a peak at P10-15. From P20-60, a reduction in the number of $\gamma \mathrm{H} 2 \mathrm{AX}$-positive cells was clearly seen also in individual preparations (Figure $3 \mathrm{~B}$ ). In adult and senescent mice, the number of positive nuclei decreased further (see also Table 1), but IR cells were still scattered throughout the SVZ/RMS/OB (Figure 3C-I).

At ultrastructural level (Figure 4), most $\gamma \mathrm{H} 2 \mathrm{AX}-\mathrm{IR}$ cells in SVZ could be identified as type $\mathrm{B}$ (astrocytes) or type $\mathrm{C}$ cells (transit amplifying cells).

The relation between H2AX phosphorylation and DNA synthesis was studied after a single injection of BrdU and two-hour survival. In these experiments, most, albeit not all, $\gamma \mathrm{H} 2 \mathrm{AX}$-positive cells in SVZ were also labeled with BrdU, and colocalization between the two labels was confirmed after immunogold labeling (Figure 4). Double IR type A (migrating neuroblasts) and type C cells were seen, but the P5-10 SVZ also contained type B and C BrdU singularly-labeled cells.

To specifically analyze the relationship between $\gamma \mathrm{H} 2 \mathrm{AX}$ expression and proliferation, double labeling IMF experiments were carried out with two different antibodies against the phosphorylated form of histone $\mathrm{H} 3$ ( $\mathrm{pHH} 3$ ) that stains cells in the $\mathrm{G}_{2}$ and $\mathrm{M}$ phase. In these experiments, all pHH3 positive nuclei in the lateral ventricular wall (Figure 3A,B) were also stained for $\gamma \mathrm{H} 2 \mathrm{AX}$. Most double-labeled nuclei were interkinetic with focal $\gamma \mathrm{H} 2 \mathrm{AX}$ nuclear distribution $\left(\mathrm{G}_{2}\right.$ phase). However, M phase cells were also dually stained. As expected, the $\gamma \mathrm{H} 2 \mathrm{AX}+\mathrm{pHH} 3$ double-labeled nuclei with characteristic $M$ phase morphologies that were detected at E 14.5 belonged to both proliferative populations recognizable in the forming cerebral wall (Figure 3A). $\gamma \mathrm{H} 2 \mathrm{AX}-\mathrm{IR}$ was demonstrated in proliferating (Figure 3C, yellow; Figure 4C, direct ultrastructural observation) and apoptotic cells (Figure 3D, red) of old mice after IMF or immunogold labeling.

Semi-quantitative data on the colocalization of $\gamma \mathrm{H} 2 \mathrm{AX}+\mathrm{pHH} 3$ are summarized in Table 2. 
Figure 3. Double immunofluorescence (IMF) labeling of $\gamma \mathrm{H} 2 \mathrm{AX}$, proliferation, and DNA synthesis markers in mouse brain. (A-D) $\gamma \mathrm{H} 2 \mathrm{AX}$ (red) + pHH3 (green) double staining in the SVZ at different ages (reference point A, see Figure 6). At E 14.5 the two populations of proliferating cells in the developing cerebral wall are double-labeled cells (yellow) with $\mathrm{M}$ (arrows) and $\mathrm{G}_{2}$ phase (arrowheads) morphologies. The area indicated by the asterisk in (A) is shown at higher magnification in the insert where the profiles of some $\mathrm{G}_{2}$ nuclei are outlined by ovals. Note the focal pattern of staining in $\mathrm{G}_{2}$ cells and the very intense labeling of condensed chromosomes in M cells. At P20 double labeled cells are for the most in $\mathrm{G}_{2}$. In the SVZ of senescent mice, $\mathrm{pHH} 3$ labeled cells are only occasionally seen. A double stained cell in $\mathrm{M}$ phase is shown in $(\mathbf{C})$, whereas the $\gamma \mathrm{H} 2 \mathrm{AX}$ intensely stained cell in (D) displays a very condensed nucleus typical of late apoptosis. (E-I) $\gamma \mathrm{H} 2 \mathrm{AX}$ (red) + BrdU (green) double IMF in senescent mice. The $\gamma \mathrm{H} 2 \mathrm{AX}-\mathrm{IR}$ nuclei (red) are indicated by asterisks and display low-to-mild focal staining or, more frequently, intense staining with chromatin condensation. BrdU-IR cells (green) and double labeled cells (yellow) are detected just below the border of the LV (E) SVZ - bregma 0.98; (F,G) RMS - reference point D; and (H) OB (reference point G, see Figure 6) are scattered in cerebral cortex ((I) reference point A, see Figure 6). Abbreviations: $\gamma \mathrm{H} 2 \mathrm{AX}=$ phosphorylated form of histone $\mathrm{H} 2 \mathrm{AX}$; $\mathrm{BrdU}=$ 5-bromo-2-deoxyuridine; $\mathrm{CPu}=$ caudate nucleus/putamen; $\mathrm{E}=$ embryonic day; $\mathrm{GrO}=$ granule cell layer of the olfactory bulb; IPl = internal plexiform layer of the olfactory bulb; IZ = intermediate zone of the cerebral wall; LV = lateral ventricle; pHH3 = phosphorylated form of histone H3; Pir = piriform cortex; SVZ = subventricular zone of the cerebral wall; and $\mathrm{VZ}=$ ventricular zone of the cerebral wall. Scale bars: (A,B,E-I) $30 \mu \mathrm{m} ;(\mathbf{C , D}) 10 \mu \mathrm{m}$.

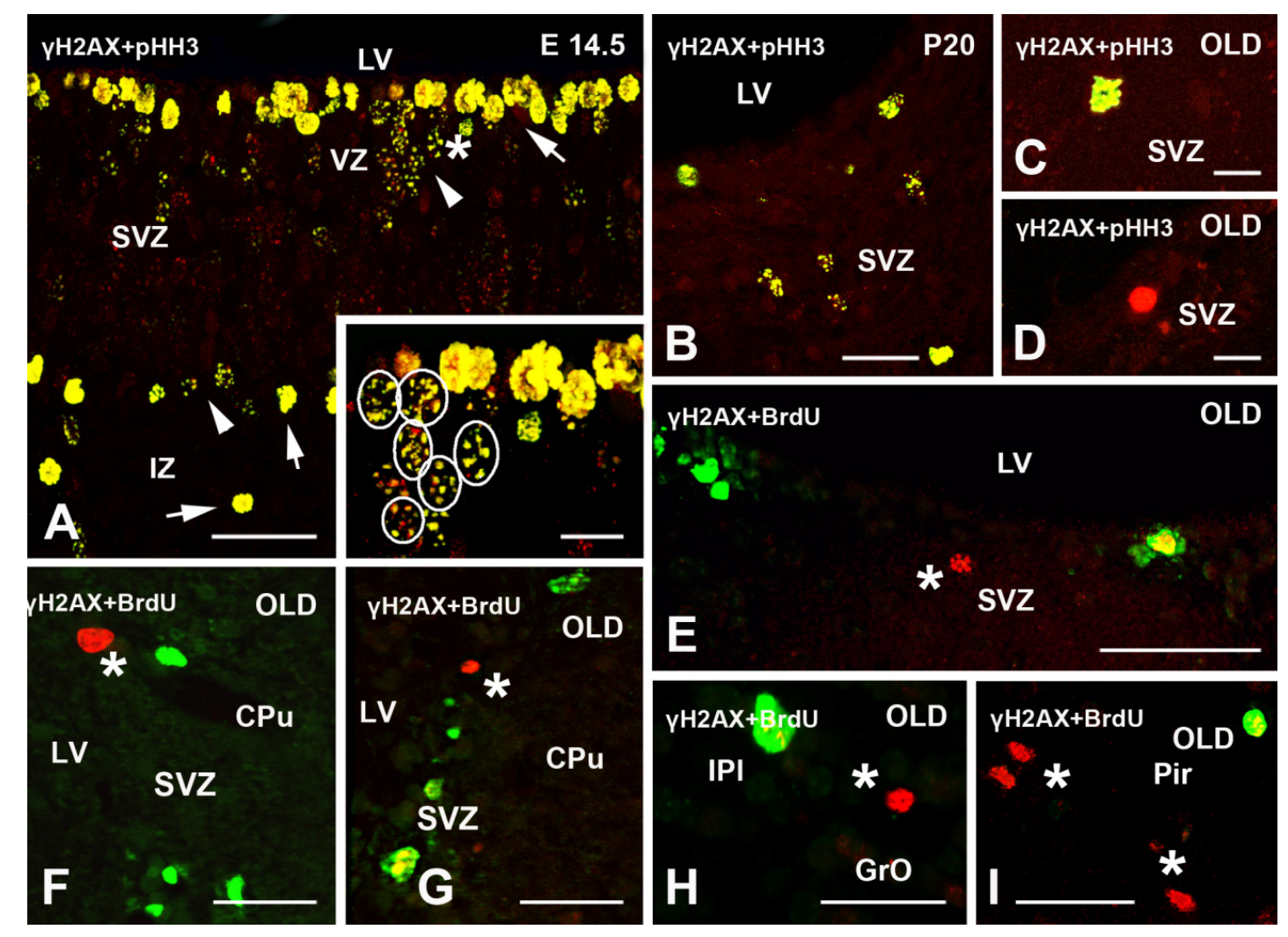


Figure 4. Double immunogold labeling for $\gamma \mathrm{H} 2 \mathrm{AX}(10 \mathrm{~nm}$ gold) and $\mathrm{BrdU}$ (20 nm gold) in SVZ. (A) Top, double-labeled type C cell with a characteristic deeply indented nucleus and chromatin lax. The areas indicated by the rectangles are shown at higher magnification in the inserts. Bottom, type A cell singularly labeled for BrdU; (B) A BrdU singularly-labeled type $\mathrm{C}$ cell (top right: right insert at top) and a double labeled type B cell (center: left insert at top); (C): Double labeled mitotic cell. The area indicated by the rectangle is displayed in the bottom left insert; and (D) Double labeled type C cell. The area in the rectangle is shown at higher magnification in the top right insert. Arrowheads indicate $10 \mathrm{~nm}$ gold, arrows $20 \mathrm{~nm}$ gold. Abbreviations: $\gamma \mathrm{H} 2 \mathrm{AX}=$ phosphorylated form of histone $\mathrm{H} 2 \mathrm{AX}$; BrdU = 5-bromo-2-deoxyuridine; $\mathrm{chr}=$ chromosomes; epe = ependyma; he = heterochromatin; $\mathrm{LV}=$ lateral ventricle; $\mathrm{P}=$ postnatal day. Scale bars: $2 \mu \mathrm{m}$; inserts: $100 \mathrm{~nm}$, except top insert in (A) $50 \mathrm{~nm}$.

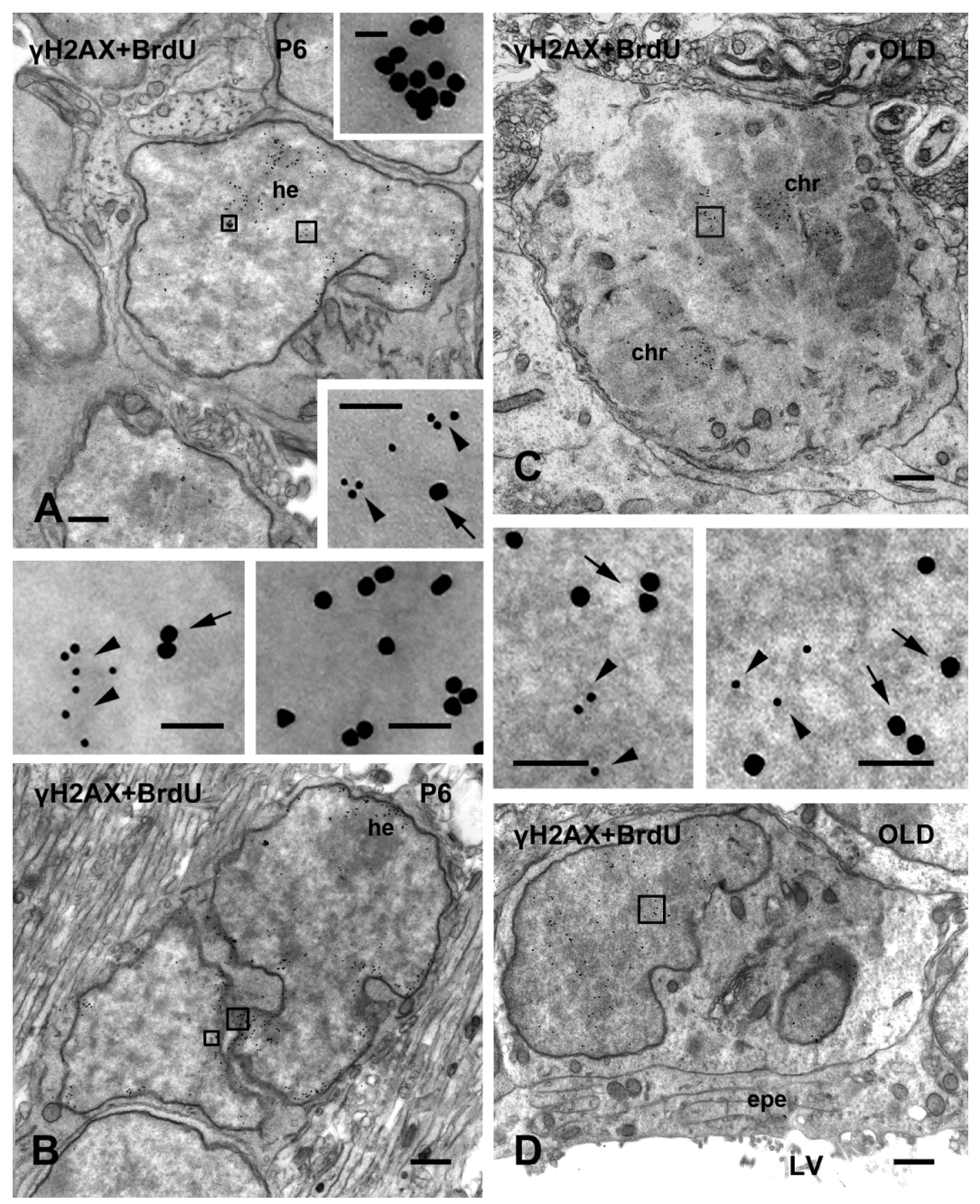


Table 2. Percentages of $\gamma \mathrm{H} 2 \mathrm{AX}$ singularly-labeled nuclei, $\mathrm{pHH} 3$ singularly-labeled nuclei and $\gamma \mathrm{H} 2 \mathrm{AX}+\mathrm{pHH} 3$ double-labeled nuclei in the SVZ in SVZ/RMS/OB and cerebellum after double IMF. At least 250 IR nuclei per age were directly observed under the confocal microscope and ascribed to any of the three categories. Abbreviations: $\gamma \mathrm{H} 2 \mathrm{AX}=$ phosphorylated form of histone $\mathrm{H} 2 \mathrm{AX}$; $\mathrm{E}=$ embryonic day; $\mathrm{P}=$ postnatal day; and $\mathrm{pHH} 3$ = phosphorylated form of histone $\mathrm{H} 3$.

\begin{tabular}{|c|c|c|c|c|c|c|}
\hline \multicolumn{7}{|c|}{ Quantification of $\gamma \mathrm{H2AX}+$ pHH3 IR nuclei in mouse $\mathrm{SVZ} / \mathrm{RMS} / \mathrm{OB}$ and cerebellum } \\
\hline \multirow{3}{*}{ Age } & \multicolumn{6}{|c|}{$\%$ of IR nuclei } \\
\hline & \multicolumn{3}{|c|}{ SVZ/MS/OB } & \multicolumn{3}{|c|}{ Cerebellum } \\
\hline & $\gamma \mathbf{H 2 A X}$ only & pHH3 only & Colocalization & $\gamma \mathbf{H 2 A X}$ only & pHH3 only & Colocalization \\
\hline E 14.5 & 29.4 & 0 & 70.6 & & & \\
\hline P0 & 22.8 & 0.8 & 76.4 & 18.8 & 1 & 80.2 \\
\hline P5 & 33.8 & 0 & 66.2 & 21.1 & 0.3 & 78.6 \\
\hline P10 & 22.2 & 1.2 & 76.6 & 8.4 & 1.6 & 90.0 \\
\hline P15 & 25.5 & 0 & 74.5 & & & \\
\hline P20 & 26.6 & 0 & 73.4 & & & \\
\hline P60 & 27.3 & 0 & 72.7 & & & \\
\hline
\end{tabular}

An additional quantitative study was carried out in cerebral cortex and SVZ/RMS/OB to compare the relationship of H2AX phosphorylation and DNA synthesis in proliferating (SVZ/RMS/OB) and postmitotic (cerebral cortex) cells. After single or multiple BrdU injection and statistical analysis, the ratio between the numbers of $\gamma \mathrm{H} 2 \mathrm{AX}+\mathrm{BrdU}$ double IR cells and BrdU-only IR cells was not statistically different among reference sections (see Experimental Section and Figure 6). It was thus possible to simply sum the data obtained from each section and calculate a mean percentage of colocalization for individual animals. Data were then separately analyzed for cerebral cortex and SVZ/RMS/OB. In cerebral cortex, the mean value of $\gamma \mathrm{H} 2 \mathrm{AX}+\mathrm{BrdU}$ colocalization was $59 \%( \pm 2.44, n=4)$ after single and 15\% $( \pm 7.0, n=4)$ after multiple BrdU administrations. The difference was statistically significant (Student's $t$-test, $p=0.002$ ). In $\mathrm{SVZ} / \mathrm{RMS} / \mathrm{OB}$, after a single BrdU injection the mean value of $\gamma \mathrm{H} 2 \mathrm{AX}+\mathrm{BrdU}$ colocalization was $47.6 \%( \pm 0.81, n=4)$. After multiple injections and statistical analysis, a difference was observed between the SVZ/RMS (reference sections A-D) and the OB (reference sections E-H). Data from sections cut through the SVZ/RMS and the OB were summed separately to calculate the percentage of colocalization of individual animals for any of the two areas. The mean value of $\gamma \mathrm{H} 2 \mathrm{AX}+\mathrm{BrdU}$ colocalization was $24.0 \%( \pm 3.55, n=4)$ in the SVZ/RMS, and $10.0 \%$ in the $\mathrm{OB}( \pm 3.55, n=4)$. These two values were significantly different (Student's $t$-test, $p=0.0098$ ).

\subsubsection{Cerebellum}

The highest intensity of $\gamma \mathrm{H} 2 \mathrm{AX}-\mathrm{IR}$ was observed in the external granular layer (EGL) of the postnatal cerebellar cortex (Figure 5). 
Figure 5. $\gamma \mathrm{H} 2 \mathrm{AX}-\mathrm{IR}$ in the postnatal mouse cerebellum and its relation with proliferation/DNA synthesis and apoptosis. (A,B) $\gamma \mathrm{H} 2 \mathrm{AX}$ (red) $+\mathrm{pHH} 3$ (green) IMF. Double-labeled nuclei (yellow) display $M$ (arrows) and $\mathrm{G}_{2}$ phase (ovals) morphologies. Singularly $\gamma \mathrm{H} 2 \mathrm{AX}$-labeled apoptotic nuclei are indicated by an asterisk. The two asterisks in $\mathrm{B}$ indicate a $\gamma \mathrm{H} 2 \mathrm{AX}-\mathrm{IR}$ interkinetic nucleus; (C,D) $\gamma \mathrm{H} 2 \mathrm{AX}$ immunogold labeling of CGCs in EGL at early (C) and mid-to-late stage (D) of apoptosis. The areas indicated by the rectangles are shown in the inserts; (E) $\gamma \mathrm{H} 2 \mathrm{AX}$ (red) + BrdU (green) double staining. Two double-labeled CGCs are indicated by asterisks, but most cells are singularly labeled; and $(\mathbf{F}, \mathbf{G})$ Double immunogold labeling for $\gamma \mathrm{H} 2 \mathrm{AX}(10 \mathrm{~nm}$ gold: arrowhead in insert) and BrdU (20 nm gold: arrow in insert). The CGC in $\mathrm{F}$ has a double-labeled interphasic nucleus. Abbreviations: $\gamma \mathrm{H} 2 \mathrm{AX}=$ phosphorylated form of histone $\mathrm{H} 2 \mathrm{AX}$; $\mathrm{ab}=$ apoptotic bodies; BrdU = 5-bromo-2-deoxyuridine; EGL = external granular layer; IGL = internal granular layer; and $\mathrm{P}=$ postnatal day. Scale bars: $(\mathbf{A}, \mathbf{B}) 10 \mu \mathrm{m} ;(\mathbf{C}, \mathbf{D}, \mathbf{F}, \mathbf{G})$ $500 \mathrm{~nm}$; and (E) $30 \mu \mathrm{m}$; inserts: (C,D,G) $15 \mathrm{~nm}$; and (F) $50 \mathrm{~nm}$.

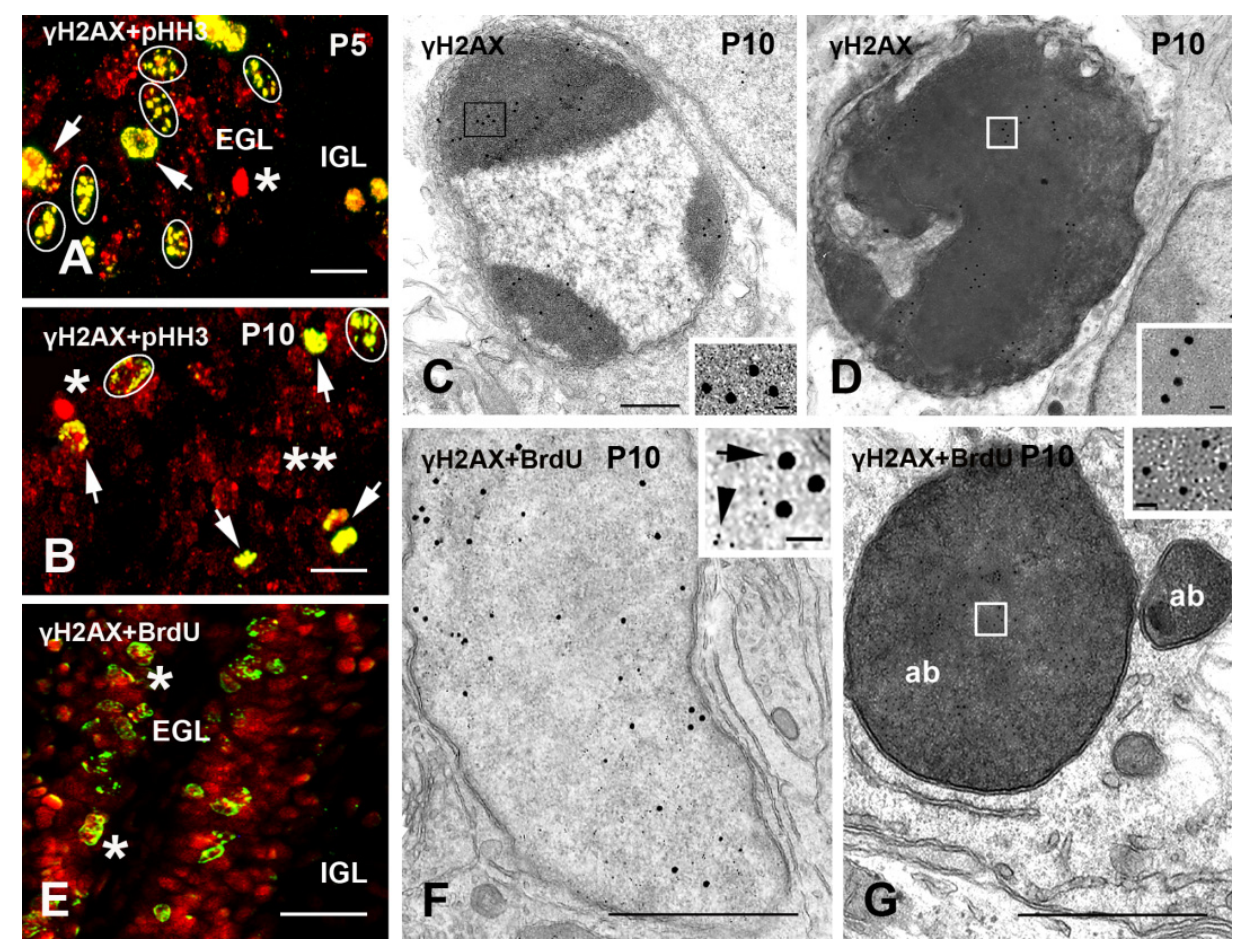

IR cells reached a peak at P5-10. They declined starting from P15 following the progressive reduction of the EGL. A few $\gamma \mathrm{H} 2 \mathrm{AX}$-positive cells were also seen in the internal granular layer (IGL) (Figure 5A). Ultrastructural examination showed labeling in interphasic (Figure 5F) mitotic, and apoptotic (Figure 5C,D,G) cerebellar granule cells (CGCs). In mitotic CGCs, gold particles were specifically associated with chromosomes, in accordance with double IMF studies. $\gamma \mathrm{H} 2 \mathrm{AX}-\mathrm{IR}$ apoptotic GCCs displayed specific staining of their nuclei and were at different stages of the apoptotic process (Figure 5C,D,G).

Similar to the SVZ/OB/RMS, the cerebellar cortex displayed colocalization of $\gamma \mathrm{H} 2 \mathrm{AX}+\mathrm{pHH} 3$ in virtually all proliferating cells, as shown by the extremely low percentages of pHH3 singularly labeled cells in colocalization studies (Table 2). On the opposite, double labeling $\gamma \mathrm{H} 2 \mathrm{AX}+\mathrm{BrdU}$ IMF experiments showed a limited degree of co-localization (Figure 5E). LM observations were confirmed 
after immunogold labeling, where $\gamma \mathrm{H} 2 \mathrm{AX}$ and BrdU co-localized only in interkinetic CGCs (Figure 5F), while $\gamma \mathrm{H} 2 \mathrm{AX}-\mathrm{IR}$ mitotic and apoptotic (Figure 5C,D,G) CGCs did not incorporate BrdU.

\section{2. $\gamma H 2 A X$ in Proliferating/Apoptotic Cells}

This is the first demonstration that $\mathrm{H} 2 \mathrm{AX}$ is phosphorylated during embryonic, postnatal and adult neurogenesis in all the areas of the intact mouse brain that display and/or retain proliferative capacity, primarily the SVZ/RMS/OB system and the cerebellar cortex. Notably, quantitative studies in these areas demonstrated a very high degree of colocalization (up to 90\%) between $\gamma \mathrm{H} 2 \mathrm{AX}$ and the cell proliferation marker $\mathrm{pHH} 3$ in IMF, and gold particles indicative of $\gamma \mathrm{H} 2 \mathrm{AX}$-IR were directly observed in $\mathrm{M}$ phase neurons at the transmission electron microscope (TEM). At both light and ultrastructural levels, $\gamma \mathrm{H} 2 \mathrm{AX}$-IR in interkinetic nuclei was mainly observed to occur in foci, albeit diffuse staining of the nucleoplasm was also evident, particularly at TEM. These observations were in part surprising since focal phosphorylation of $\mathrm{H} 2 \mathrm{AX}$ is currently believed to be primarily related to DNA damage [1,2,4,16,17,24], and a global pan-nuclear $\gamma \mathrm{H} 2 \mathrm{AX}$ DNA staining has previously been observed in M phase cells [12].

$\gamma \mathrm{H} 2 \mathrm{AX}$ was detectable from embryonic life to senescence in the SVZ/RMS/OB system. It is a well-established notion that in the (mouse) brain, the SVZ is a neurogenic stem cell niche that persists throughout life, albeit progressively reducing with senescence [25-27]. Numerous studies on the SVZ/RMS/OB system have used (and often misused) the S phase marker BrdU to detect proliferating cells. The striking difference in the degree of colocalization of $\gamma \mathrm{H} 2 \mathrm{AX}$ with the "true" proliferation marker pHH3 from one side and BrdU from the other indicates that a substantial number of S phase cells in the SVZ/RMS/OB system express $\gamma \mathrm{H} 2 \mathrm{AX}$, suggesting that BrdU incorporation may, in these cells, be related to a DDR. A reduction of BrdU incorporation in the SVZ of elderly mice was previously reported, and it was speculated that an increased cell death was responsible for lowering the number of S phase cells in the elderly [27]. Apoptotic cells in the SVZ/RMS/OB were so rare in our material, and we found no direct evidence for an increase of apoptotic cells in the senescent mouse SVZ. However, after multiple injections of BrdU we demonstrated a statistically significant difference in the percentage $\gamma \mathrm{H} 2 \mathrm{AX}+\mathrm{BrdU}$ double-labeled cells in the SVZ/RMS (the proliferative compartment) compared to the $\mathrm{OB}$ (the receptive compartment), with a reduction to 0.41 fold in the latter. Migration of neural precursors from SVZ to the OB along the RMS is a well-established phenomenon [25-27]. Therefore, the relative disappearance of $\gamma \mathrm{H} 2 \mathrm{AX}$ in the foremost part of the system indicates that effective DDR mechanisms occur as migrating cells travel towards the OB.

Another site of the brain where neurogenesis is paralleled by an intense phosphorylation of H2AX is the developing cerebellar cortex, wherein actively mitotic precursors generate the CGCs that migrate eventually to the IGL. Here, an important neurogenetic wave occurs during the first two postnatal weeks, in parallel with the peak of $\mathrm{H} 2 \mathrm{AX}$ phosphorylation. Therefore, the time course of $\gamma \mathrm{H} 2 \mathrm{AX}-\mathrm{IR}$ displays a direct correlation with the process of CGC differentiation/maturation [28], so that the degree of colocalization between $\gamma \mathrm{H} 2 \mathrm{AX}-\mathrm{IR}$ and $\mathrm{pHH} 3$ reaches values of $80 \%-90 \%$. Differently from the SVZ/RMS/OB system, $\gamma \mathrm{H} 2 \mathrm{AX}-\mathrm{IR}$ could also be easily detected in CGCs with the typical ultrastructural features of early and late apoptosis. In keeping with our previous studies demonstrating that apoptotic cell death rapidly follows proliferation in a large population of CGCs [28], 
$\gamma \mathrm{H} 2 \mathrm{AX}$ immunoreactivity was observed in these neurons together with the $\mathrm{S}$ phase marker BrdU as soon as after two hours from administration of the tracer (Figure 5G). Thus our data indicate $\gamma \mathrm{H} 2 \mathrm{AX}$ as an important signal for the cell to commit itself to apoptosis, and lead to speculate that $\mathrm{H} 2 \mathrm{AX}$ phosphorylation, besides being one of the first DDR signals, may subsequently represent a marker of the persistence of residual DNA damages. This study unequivocally demonstrates that $\mathrm{H} 2 \mathrm{AX}$ is phosphorylated in proliferating neurons. However, it leaves open the question whether or not activation of $\mathrm{H} 2 \mathrm{AX}$ is indeed related to the occurrence of DNA DSBs during cell division, apoptosis or, simply, to physiological activity, as recently demonstrated in hippocampus [29]. Hematopoietic stem cells or jejunum epithelial stem cells display strong levels of DSB repair activity under normal conditions [30,31]. Therefore, it is possible that similar events also occur in proliferating neurons. The possibility that neuronal activation of $\mathrm{H} 2 \mathrm{AX}$ simply occurs during mitosis (i.e., strictly speaking, the M phase) [12] can, instead, be ruled out on the basis of our observations, although H2AX has also been implicated, together with $\mathrm{HH} 3$, in chromosome condensation [32]. Although the biological function of $\mathrm{H} 2 \mathrm{AX}$ during mitosis (if any) remains to be elucidated in full, it was recently shown that its phosphorylation blocks DNA synthesis and cell cycle progression in neural stem cells, and that their self-renewal and the niche size can be dynamically modulated by targeting H2AX activation [33,34].

Given that a block of cell cycle progression is often associated with cell death in neurons, the occurrence of $\gamma \mathrm{H} 2 \mathrm{AX}$ in apoptosis [1,35] deserves further discussion. Initial studies demonstrated that apoptotic DNA fragmentation resulted in H2AX phosphorylation as a DDR [36], suggesting that $\mathrm{H} 2 \mathrm{AX}$ activation is a consequence of apoptosis. However, other experiments indicated that, instead, activation of $\mathrm{H} 2 \mathrm{AX}$ may precede apoptosis rather than follow it, because H2AX contributes to the apoptotic process by altering the chromatin conformation and increasing the accessibility of DNA to apoptotic effectors [36,37]. In the case of the CGCs, where close temporal links (as short as twenty four hours) have been demonstrated between DNA synthesis ( $\mathrm{S}$ phase) and apoptosis [28], localization of $\gamma \mathrm{H} 2 \mathrm{AX}$ in early apoptotic cerebellar neurons suggests that phosphorylation of H2AX occurs once CGCs are already committed to death. This is further reinforced by the colocalization of $\gamma \mathrm{H} 2 \mathrm{AX}+\mathrm{BrdU}$ in CGCs with a normal interkinetic nucleus, as we have previously demonstrated that some of these neurons display a fragmented DNA in the presence of an ultrastructurally unaltered nucleus [28]. It is worth mentioning here that a link between apoptosis and a deregulated cell cycle has been implicated in the pathophysiology of different neurodegenerative diseases [38]. Therefore, it is tempting to speculate that targeting $\mathrm{H} 2 \mathrm{AX}$ might represent a promising neuroprotective strategy to pursue for the future.

\section{3. $\gamma H 2 A X$ in Postmitotic Cells}

The cerebral cortex resulted in being a major site of expression of $\gamma \mathrm{H} 2 \mathrm{AX}$ in fully mature and senescent mice. For the most, $\gamma \mathrm{H} 2 \mathrm{AX}$ immunoreactivity was detected in nuclei belonging to NeuN-positive neurons, but also some GFAP-IR astrocytes had a positive nucleus. In both types of cells, IR nuclei were interkinetic with a focal distribution of $\gamma \mathrm{H} 2 \mathrm{AX}$. There was no co-localization with the proliferation marker $\mathrm{pHH} 3$. The only occasional $\mathrm{pHH} 3$ singularly labeled nuclei belonged to non-neural cells, i.e., some endothelial cells in blood vessels.

In the cerebral cortex of senescent animals, the exclusively focal appearance of $\gamma \mathrm{H} 2 \mathrm{AX}-\mathrm{IR}$ and the high percentage of $\gamma \mathrm{H} 2 \mathrm{AX}+\mathrm{BrdU}$ colocalization (about 60\%) indicate that $\mathrm{BrdU}$ incorporation is 
primarily related to a DDR occurring in postmitotic neurons and glial cells. Quantitative analysis demonstrated that the percentage of cortical cells expressing the two labels versus the total number of BrdU-labeled cells underwent minimal fluctuations along the rostro-caudal axis of telencephalon. This indicates that the senescent cerebral cortex, as a whole, is prone to DNA damage, very likely in the form of DSBs. Further experiments are needed to definitively prove or disprove the occurrence of DSBs, as it was previously shown-albeit in a transformed fibroblast cell line-that cellular senescence can also be associated with a pseudo DDR, i.e., $\gamma \mathrm{H} 2 \mathrm{AX}$ foci in the absence of detectable DNA breaks [39].

Data on the temporal distribution of $\mathrm{H} 2 \mathrm{AX}$ phosphorylation after ionizing radiations demonstrated that, after a short plateau of approximately one hour, the number of $\gamma \mathrm{H} 2 \mathrm{AX}$ foci started to decrease two hours post-irradiation and returned to baseline within six hours [40]. Although these data are difficult to compare with the situation in vivo, they are in line with the notion that $\gamma \mathrm{H} 2 \mathrm{AX}$ rapidly returns to baseline once repair has been successful. Therefore, we can reasonably assume that cortical cells, which incorporated BrdU but were negative to $\gamma \mathrm{H} 2 \mathrm{AX}$, are committed to death, in agreement with the known intervention of $\gamma \mathrm{H} 2 \mathrm{AX}$ in the modulation of checkpoint responses [41]. DNA repair systems in the absence of an external insult should be of great importance in the adult and old brain [42-44], and efficient DNA repair is needed in long-living cells with no or limited regeneration from precursors, such is the case of adult/senescent cortical neurons (and glia). Molecular/pharmacological targeting of these systems has a good potential for development of novel neuroprotective strategies. In cells with a very long life span such as neural cells, adipocytes and muscle fibers, a common paradigm of DSB repair has been observed after biochemical and in vitro experiments. Similarly to neurons, adipocytes have a very slow turnover in the adult [45] and a study on the pre-adipocyte cell line 3T3F442A demonstrated that DNA repair activity increased in postmitotic cells, in opposition to the view that DSB repair was decreased during differentiation [46]. An active process of protection against DNA DSBs was also observed in differentiated myotubes. It counteracted the consequences of DNA damage, but was not detected in myoblasts, the less differentiated precursors of the muscle fibers [47]. Thus, it was hypothesized that differentiated long-lived cells such as the neurons and the muscle fibers acquire active mechanisms that hamper the effects of DNA DSBs as compared to their less-differentiated precursors $[47,48]$. The work presented here gives strong support to this hypothesis.

\section{Experimental Section}

\subsection{Animals}

All experimental procedures were approved by the Italian Ministry of Health and the Committee of Bioethics and Animal Welfare of the University of Torino, Torino, Italy.

Labeling of DNA synthesis in vivo was carried out as follows. BrdU (Sigma, St. Louis, MO, USA) was dissolved in sterile water at $100 \mathrm{mg} / \mathrm{mL}$ and injected intraperitoneally at $0.1 \mathrm{mg} / \mathrm{g}$ body weight. A single BrdU injection was given to animals [two postnatal day 6 (P6), two P10 and two 24 months old mice for electron microscopy (EM) studies, and six 24 months old mice for light microscopy (LM) studies] followed by a two-hour survival. Six additional 24 months old mice received a daily BrdU injection for one week, followed by sacrifice twenty four hours after the last administration of the 
tracer, and were employed for LM studies. The immunocytochemical visualization of $\gamma \mathrm{H} 2 \mathrm{AX}-\mathrm{IR}$ was performed on embryonic (E 14.5), postnatal (P0, P5, P10, P15, and P20), adult (P60), and senescent $(18,24$ months) mice (four at each age). Three mice for each postnatal age (P0, P5, P10, P15, $\mathrm{P} 20$, and $\mathrm{P} 60)$ were used for detection of $\gamma \mathrm{H} 2 \mathrm{AX}$ in brain tissue homogenates.

\subsection{Immunocytochemistry}

Animals (untreated or treated with BrdU) were deeply anesthetized with an intraperitoneal injection of sodium pentobarbital $(30 \mathrm{mg} / \mathrm{kg}$ ), and perfused with $4 \%$ paraformaldehyde (PFA) in $0.1 \mathrm{M}$ phosphate buffer (PB) for LM or 2\% glutaraldehyde $+1 \%$ PFA in $0.05 \mathrm{M}$ sodium cacodylate buffer for EM. After dissection, brains were left in fixative for two hours. Embedding (paraffin or Araldite) and cutting were carried out according to standard procedures.

The light microscopy ICC detection of $\gamma \mathrm{H} 2 \mathrm{AX}$ and related molecules was performed by the ABC method or double IMF.

The semi-quantitative analysis of the distribution of $\gamma \mathrm{H} 2 \mathrm{AX}$ reported in Table 1 was carried out by counting, for each animal, the number of $\gamma \mathrm{H} 2 \mathrm{AX}-\mathrm{IR}$ nuclei in individual areas of the brain from five coronal sections cut through the forebrain (P60/OLD: bregma $-2.18,-1.22,0.98,1.34$, and 3.56; see also Figure 1), one section cut through the midbrain (P60/OLD: bregma between -4.04 and -4.60 ), and one section cut through the hindbrain (P60/OLD: bregma between -6.00 and -6.64 ). Parasagittal sections of the brain in toto were used in E 14.5 embryos. Results were averaged for each group of age, and reported according to the following scale: - = no signal, i.e., 0 IR nuclei; $+=$ weak staining, i.e., $\leq 10$ IR nuclei; $++=$ moderate staining, i.e., $>10$ and $\leq 50$ IR nuclei; $+++=$ strong staining, i.e., $>50$ IR nuclei.

The percentages of $\gamma \mathrm{H} 2 \mathrm{AX}$ singularly-labeled cells, pHH3 singularly-labeled cells, and $\gamma \mathrm{H} 2 \mathrm{AX}+\mathrm{pHH} 3$ double-labeled cells were calculated at different ages after double IMF on randomly selected sections from at least three different animals/age. At least 250 immunolabeled cells per age were directly observed under the confocal microscope.

Electron microscopic ICC was performed using single and double immunogold standard labeling procedures.

\subsection{Western Blotting}

Brains were quickly removed and frozen in liquid nitrogen, powdered and suspended in 2.5 volumes of a cold general lysis buffer (50 mM Pipes, $300 \mathrm{mM}$ Sucrose, $100 \mathrm{mM} \mathrm{NaCl}$, $5 \mathrm{mM}$ EGTA, $5 \mathrm{mM} \mathrm{HgCl}$, $100 \mu \mathrm{M} \mathrm{ZnCl}_{2}$, $1 \mathrm{mM}$ Sodium orthovanadate, Triton $\mathrm{X}-100$ 1\%, pH 6.8) containing protease inhibitors ( $1 \mathrm{mM} \mathrm{PMSF}$, and $5 \mathrm{mg} / \mathrm{mL}$ aprotinin). The homogenate was sonicated and centrifuged at $1.2 \times 10^{4} \mathrm{~g} / \mathrm{min}$ at $4{ }^{\circ} \mathrm{C}$ for $10 \mathrm{~min}$. The immunological detection of $\gamma \mathrm{H} 2 \mathrm{AX}$ in brain extracts was carried out after immunoprecipitation following standard procedures.

\subsection{Primary Antibodies}

Table 3 reports a list of primary antibodies, with characteristics, conditions of use and relevant references where available. 
Table 3. Primary antibodies. Abbreviations: $\gamma \mathrm{H} 2 \mathrm{AX}=$ phosphorylated form of histone $\mathrm{H} 2 \mathrm{AX} ; \mathrm{BrdU}=$ 5-bromo-2-deoxyuridine; GFAP $=$ glial fibrillary acidic protein; ICC EM = immunocytochemistry electron microscopy; ICC LM = immunocytochemistry light microscopy; $\mathrm{M}=$ mouse; $\mathrm{NA}=$ not available; NeuN = Neuronal nuclei antigen; pHH3 = phosphorylated form of histone $\mathrm{H} 3 ; \mathrm{R}=$ rabbit; and $\mathrm{WB}=$ Western blotting.

\begin{tabular}{|c|c|c|c|c|c|c|}
\hline \multicolumn{7}{|c|}{ Primary antibodies } \\
\hline Antibodies & Target/epitope & Type & Dilution & Use & Supplier & Refs \\
\hline $\begin{array}{l}\gamma \mathrm{H} 2 \mathrm{AX} \\
(\mathrm{Ser} 139) \\
\end{array}$ & $\begin{array}{c}\text { aa } 134-142 \text { of human H2AX } \\
\text { (C-KATQA[pS]QEY) }\end{array}$ & Mono, $\mathrm{M}$ & $1: 200$ & ICC LM & $\begin{array}{l}\text { Upstate Biotechnology, } \\
\text { Lake Placid, NY, USA }\end{array}$ & NA \\
\hline $\begin{array}{l}\gamma \mathrm{H} 2 \mathrm{AX} \\
(\mathrm{Ser} 139)\end{array}$ & $\begin{array}{c}\text { aa 134-142 of human H2AX } \\
\text { (C-KATQA[pS]QEY) }\end{array}$ & Poly, R & $1: 500$ & $\begin{array}{l}\text { ICC LM } \\
\text { WB }\end{array}$ & $\begin{array}{c}\text { Millipore, Billerica, } \\
\text { MA, USA }\end{array}$ & NA \\
\hline $\begin{array}{l}\gamma \mathrm{H} 2 \mathrm{AX} \\
(\operatorname{Ser} 139)\end{array}$ & $\begin{array}{c}\text { Residues surrounding Ser139 of } \\
\text { human H2AX }\end{array}$ & Poly, R & $1: 25$ & ICC EM & $\begin{array}{c}\text { Cell Signaling } \\
\text { Technology, Danvers, } \\
\text { MA, USA } \\
\end{array}$ & NA \\
\hline $\mathrm{pHH} 3$ & $\begin{array}{l}\text { aa } 1-100 \text { of human } \mathrm{HH} 3, \\
\text { phosphorylated at Ser10 }\end{array}$ & Poly, R & $1: 2000$ & ICC LM & $\begin{array}{c}\text { Abcam, Cambridge, } \\
\text { UK }\end{array}$ & [49] \\
\hline $\mathrm{pHH} 3$ & $\begin{array}{c}\text { aa } 7-20 \text { of human HH3 } \\
\text { (ARKpSTGGKAPRKQLC) }\end{array}$ & Poly, R & $1: 1000$ & ICC LM & $\begin{array}{l}\text { Upstate Biotechnology, } \\
\text { Lake Placid, NY, USA }\end{array}$ & {$[50]$} \\
\hline BrdU & $\begin{array}{l}\text { Exogenously administered } \\
\text { BrdU }\end{array}$ & Mono, $\mathrm{M}$ & $1: 5$ & ICC LM & $\begin{array}{c}\text { GE Healthcare, } \\
\text { Chalfont St. Giles, UK }\end{array}$ & {$[51]$} \\
\hline BrdU & $\begin{array}{c}\text { Exogenously administered } \\
\text { BrdU }\end{array}$ & $\begin{array}{c}\text { Mono, } \\
\text { Rat }\end{array}$ & $1: 10$ & ICC EM & $\begin{array}{c}\text { AbD Serotec, Oxford, } \\
\text { UK }\end{array}$ & {$[52]$} \\
\hline NeuN & $\begin{array}{l}\text { Purified neuronal nuclei from } \\
\text { mouse brain }\end{array}$ & Mono, $\mathrm{M}$ & $1: 100$ & ICC LM & $\begin{array}{c}\text { Millipore (Chemicon), } \\
\text { Billerica, MA, USA }\end{array}$ & {$[53]$} \\
\hline GFAP & $\begin{array}{l}\text { GFAP purified from bovine } \\
\text { spinal cord after Triton X-100 } \\
\text { extraction }\end{array}$ & Poly, R & $1: 2000$ & ICC LM & $\begin{array}{c}\text { Abcam, Cambridge, } \\
\text { UK }\end{array}$ & {$[54]$} \\
\hline
\end{tabular}

\subsection{Quantitative Studies on $\gamma H 2 A X+B r d U$ Colocalization in Senescent Mice and Statistics}

Quantitative studies on $\gamma \mathrm{H} 2 \mathrm{AX}+\mathrm{BrdU}$ colocalization were carried out in series of eight sections cut through the forebrain of senescent mice (Figure 6). Eight slides/animal (each bearing the three serial sections that immediately followed the toluidine blue-stained reference sections) were used for double immunocytochemical labeling quantitative studies. Single and double-labeled immunoreactive cells were directly counted in a single plane of focus with a DM6000B fluorescence microscope (Leica Microsystems, Weitzlar, Germany) at 40× magnification.

Statistics was carried out with the SPSS software (IBM, Armonk, NY, USA). For $\gamma \mathrm{H} 2 \mathrm{AX}+\mathrm{BrdU}$ colocalization, mean percentages of labeled cells in experimental animals were compared with one-way ANOVA and the Student's $t$-test with the Bonferroni correction. Differences were considered significant for $p<0.05$. 
Figure 6. Coronal reference sections used for quantitative studies of $\gamma \mathrm{H} 2 \mathrm{AX}+\mathrm{BrdU}$ colocalization in senescent mice. Red bars (A to $\mathbf{H})$ indicate the stereotaxic coordinates of individual coronal sections with respect to a sagittal section of the adult mouse brain (adapted from [23]). For anatomical mapping, the entire forebrain was serially cut along the rostro-caudal axis at $6 \mu \mathrm{m}$, and coronal sections at $750 \mu \mathrm{m}$ intervals were stained with toluidine blue for identification of anatomical reference structures. The eight reference points were identified as follows: A, hippocampus (bregma $-2.18 \mathrm{~mm}$ ); $\mathbf{B}$, interventricular foramem (bregma $-0,22 \mathrm{~mm}$ ); $\mathbf{C}$, lateral ventricle at the point of alignment with the anterior arm of corpus callosum (bregma $0.62 \mathrm{~mm}$ ); D, maximal reduction of lateral ventricle extension, corresponding to start of the RMS (bregma $1.34 \mathrm{~mm}$ ); $\mathbf{E}, \mathrm{RMS}$ at the level of intersection of rhinal fissure with a line tangent to the lateral margin of the intrabulbar portion of the anterior arm of corpus callosum (bregma $2.10 \mathrm{~mm}$ ); F, end of RMS at the level of first stratification of olfactory bulb (bregma $2.80 \mathrm{~mm}$ ); $\mathbf{G}$, olfactory bulb at the level of the rostral margin of the accessory olfactory bulb (bregma: $3.56 \mathrm{~mm}$ ); and $\mathbf{H}$, olfactory bulb (bregma $4.28 \mathrm{~mm}$ ).

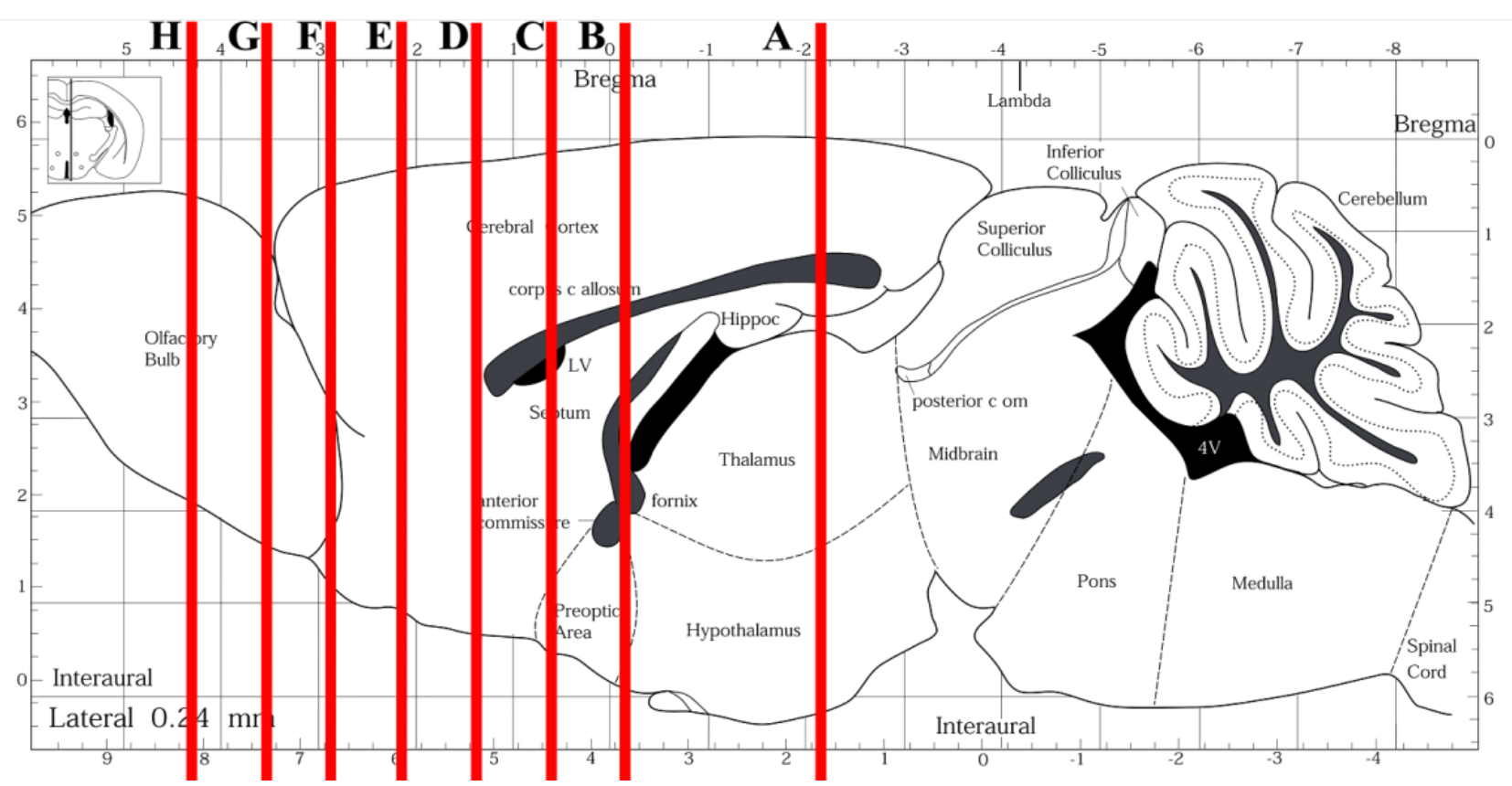

\section{Conclusions}

This study demonstrates that $\gamma \mathrm{H} 2 \mathrm{AX}$ is expressed in the mouse brain from embryonic life to senescence in the absence of experimentally evoked damage to cellular DNA. Focal and non-focal phosphorylation of $\mathrm{H} 2 \mathrm{AX}$ in neurogenetic areas of forebrain and cerebellum is linked to cell proliferation, which, in neural stem cells, has been previously shown to be regulated in a different manner from most somatic cells with a fundamentally distinct mechanism of DDR and checkpoints [33]. On the other hand, in cerebral cortex of senescent mice the appearance of $\gamma \mathrm{H} 2 \mathrm{AX}$-IR foci is most likely related to DSB occurrence and repair. As excessive glutamate stimulation $[19,20]$ increased activity, and $\beta$-amyloid [29] can induce DSBs, our study indicates that H2AX phosphorylation may be a response of the normal postmitotic neurons to an array of physiological and/or pathological situations eventually leading to a DDR and/or a pseudo DDR. 
Therefore, targeting $\mathrm{H} 2 \mathrm{AX}$ and/or DDR-related molecules looks to be a promising strategy to develop new approaches to counteract neurodegeneration, as the loss of function of DDR proteins (among which $\gamma \mathrm{H} 2 \mathrm{AX}$ ) appears to be tightly linked to several neurodegenerative diseases [55].

\section{Acknowledgments}

This work was supported by grants to LL and AM (MIUR-Prin 2008/2009 and University of Turin).

\section{Author Contributions}

Serena Barral performed light microscopy immunocytochemical experiments, $\gamma \mathrm{H} 2 \mathrm{AX}$ distribution studies and western blots. Riccardo Beltramo performed quantitative studies of $\gamma \mathrm{H} 2 \mathrm{AX}+\mathrm{BrdU}$ colocalization in senescent mice. Chiara Salio performed TEM studies in cerebellum. Patrizia Aimar performed TEM studies in SVZ. Laura Lossi and Adalberto Merighi conceived and designed the experiments, supervised the project, interpreted the data, and wrote the manuscript.

\section{Conflicts of Interest}

The authors declare no conflict of interest.

\section{References}

1. Rogakou, E.P.; Pilch, D.R.; Orr, A.H.; Ivanova, V.S.; Bonner, W.M. DNA double-stranded breaks induce histone H2AX phosphorylation on serine 139. J. Biol. Chem. 1998, 273, 5858-5868.

2. Rogakou, E.P.; Boon, C.; Redon, C.; Bonner, W.M. Megabase chromatin domains involved in DNA double-strand breaks in vivo. J. Cell. Biol. 1999, 146, 905-916.

3. Rothkamm, K.; Löbrich, M. Evidence for a lack of DNA double-strand break repair in human cells exposed to very low X-ray doses. Proc. Natl. Acad. Sci. USA 2003, 100, 5057-5062.

4. Sedelnikova, O.A.; Rogakou, E.P.; Panyutin, I.G.; Bonner, W.M. Quantitative detection of 125 IdU-induced DNA double-strand breaks with $\gamma$-H2AX antibody. Radiat. Res. 2002, 158, 486-492.

5. Sedelnikova, O.A.; Horikawa, I.; Zimonjic, D.B.; Popescu, N.C.; Bonner, W.M.; Barrett, J.C. Senescing human cells and ageing mice accumulate DNA lesions with unrepairable double-strand breaks. Nat. Cell Biol. 2004, 6, 168-170.

6. Hesse, J.E.; Faulkner, M.F.; Durdik, J.M. Increase in double-stranded DNA break-related foci in early-stage thymocytes of aged mice. Exp. Gerontol. 2009, 44, 676-684.

7. Wang, C.; Jurk, D.; Maddick, M.; Nelson, G.; Martin-Ruiz, C.; von Zglinicki, T. DNA damage response and cellular senescence in tissues of aging mice. Aging Cell 2009, 8, 311-323.

8. Sedelnikova, O.A.; Horikawa, I.; Redon, C.; Nakamura, A.; Zimonjic, D.B.; Popescu, N.C.; Bonner, W.M. Delayed kinetics of DNA double-strand break processing in normal and pathological aging. Aging Cell 2008, 7, 89-100.

9. Villaret, A.; Galitzky, J.; Decaunes, P.; Estève, D.; Marques, M.A.; Sengenès, C.; Chiotasso, P.; Tchkonia, T.; Lafontan, M.; Kirkland, J.L.; et al. Adipose tissue endothelial cells from obese human subjects: Differences among depots in angiogenic, metabolic, and inflammatory gene expression and cellular senescence. Diabetes 2010, 592, 755-763. 
10. Bonner, W.M.; Redon, C.E.; Dickey, J.S.; Nakamura, A.J.; Sedelnikova, O.A.; Solier, S.; Pommier, Y. $\gamma$-H2AX and cancer. Nat. Rev. Cancer 2008, 8, 957-967.

11. Dickey, J.S.; Redon, C.E.; Nakamura, A.J.; Baird, B.J.; Sedelnikova, O.A.; Bonner, W.M. H2AX: Functional roles and potential applications. Chromosoma 2009, 118, 683-692.

12. Ichijima, Y.; Sakasai, R.; Okita, N.; Asahina, K.; Mizutani, S.; Teraoka, H. Phosphorylation of histone $\mathrm{H} 2 \mathrm{AX}$ at $\mathrm{M}$ phase in human cells without DNA damage response. Biochem. Biophys. Res. Commun. 2005, 336, 807-812.

13. Löbrich, M.; Shibata, A.; Beucher, A.; Fisher, A.; Ensminger, M.; Goodarzi, A.A.; Barton, O.; Jeggo, P.A. $\gamma$-H2AX foci analysis for monitoring DNA double-strand break repair: Strengths, limitations and optimization. Cell Cycle 2010, 9, 662-669.

14. Costes, S.V.; Chiolo, I.; Pluth, J.M.; Barcellos-Hoff, M.H.; Jakob, B. Spatiotemporal characterization of ionizing radiation induced DNA damage foci and their relation to chromatin organization. Mutat. Res. 2010, 704, 78-87.

15. Spalding, K.L.; Bergmann, O.; Alkass, K.; Bernard, S.; Salehpour, M.; Huttner, H.B.; Boström, E.; Westerlund, I.; Vial, C.; Buchholz, B.A.; et al. Dynamics of hippocampal neurogenesis in adult humans. Cell 2013, 153, 1219-1227.

16. Brasnjevic, I.; Hof, P.R.; Steinbusch, H.W.; Schmitz, C. Accumulation of nuclear DNA damage or neuron loss: Molecular basis for a new approach to understanding selective neuronal vulnerability in neurodegenerative diseases. DNA Repair 2008, 7, 1087-1097.

17. Ward, I.; Chen, J. Early events in the DNA damage response. Curr. Top. Dev. Biol. 2004, 63, 1-35.

18. Nowak, E.; Etienne, O.; Millet, P.; Lages, C.S.; Mathieu, C.; Mouthon, M.A.; Boussin, F.D. Radiation-induced H2AX phosphorylation and neural precursor apoptosis in the developing brain of mice. Radiat. Res. 2006, 165, 155-164.

19. Crowe, S.L.; Movsesyan, V.A.; Jorgensen, T.J.; Kondratyev, A. Rapid phosphorylation of histone H2A.X following ionotropic glutamate receptor activation. Eur. J. Neurosci. 2006, 23, 2351-2361.

20. Crowe, S.L.; Tsukerman, S.; Gale, K.; Jorgensen, T.J.; Kondratyev, A.D. Phosphorylation of histone H2A.X as an early marker of neuronal endangerment following seizures in the adult rat brain. J. Neurosci. 2011, 31, 7648-7656.

21. Myung, N.H.; Zhu, X.; Kruman, I.I.; Castellani, R.J.; Petersen, R.B.; Siedlak, S.L.; Perry, G.; Smith, M.A.; Lee, H.G. Evidence of DNA damage in Alzheimer disease: Phosphorylation of histone H2AX in astrocytes. Age 2008, 30, 209-215.

22. Jeon, G.S.; Kim, K.Y.; Hwang, Y.J.; Jung, M.K.; An, S.; Ouchi, M.; Ouchi, T.; Kowall, N.; Lee, J.; Ryu, H. Deregulation of BRCA1 leads to impaired spatiotemporal dynamics of $\gamma$-H2AX and DNA damage responses in Huntington's disease. Mol. Neurobiol. 2012, 45, 550-563.

23. Paxinos, G.; Franklin, K.B.J. The Mouse Brain in Stereotaxic Coordinates, 2nd Ed.; Elsevier Academic Press: San Diego, CA, USA, 2004.

24. Sedelnikova, O.A.; Pilch, D.R.; Redon, C.; Bonner, W.M. Histone H2AX in DNA damage and repair. Cancer Biol. Ther. 2003, 2, 233-235.

25. Jin, K.; Sun, Y.; Xie, L.; Batteur, S.; Mao, X.O.; Smelick, C.; Logvinova, A.; Greenberg, D.A. Neurogenesis and aging: FGF-2 and HB-EGF restore neurogenesis in hippocampus and subventricular zone of aged mice. Aging Cell 2003, 2, 175-183. 
26. Maslov, A.Y.; Barone, T.A.; Plunkett, R.J.; Pruitt, S.C. Neural stem cell detection, characterization, and age-related changes in the subventricular zone of mice. J. Neurosci. 2004, 24, 1726-1733.

27. Luo, J.; Daniels, S.B.; Lennington, J.B.; Notti, R.Q.; Conover, J.C. The aging neurogenic subventricular zone. Aging Cell 2006, 5, 139-152.

28. Lossi, L.; Mioletti, S.; Merighi, A. Synapse-independent and synapse-dependent apoptosis of cerebellar granule cells in postnatal rabbits occur at two subsequent but partly overlapping developmental stages. Neuroscience 2002, 112, 509-523.

29. Suberbielle, E.; Sanchez, P.E.; Kravitz, A.V.; Wang, X.; Ho, K.; Eilertson, K.; Devidze, N.; Kreitzer, A.C.; Mucke, L. Physiologic brain activity causes DNA double-strand breaks in neurons, with exacerbation by amyloid- $\beta$. Nat. Neurosci. 2013, 16, 613-621.

30. Murray, D.; Meyn, R.E. Differential repair of gamma-ray-induced DNA strand breaks by various cellular subpopulations of mouse jejunal epithelium and bone marrow in vivo. Radiat. Res. 1987, 109, 153-164.

31. Tabocchini, M.A.; Rothkamm, K.; Signoretti, C.; Risse, J.; Sapora, O.; Lobrich, M. Formation and repair of DNA double-strand breaks in gamma-irradiated K562 cells undergoing erythroid differentiation. Mutat. Res. 2000, 461, 71-82.

32. Van Hooser, A.; Goodrich, D.W.; Allis, C.D.; Brinkley, B.R.; Mancini, M.A. Histone H3 phosphorylation is required for the initiation; but not maintenance; of mammalian chromosome condensation. J. Cell Sci. 1998, 111, 3497-3506.

33. Andang, M.; Hjerling-Leffler, J.; Moliner, A.; Lundgren, T.K.; Castelo-Branco, G.; Nanou, E.; Pozas, E.; Bryja, V.; Halliez, S.; Nishimaru, H.; et al. Histone H2AX-dependent GABA receptor regulation of stem cell proliferation. Nature 2008, 451, 460-464.

34. Fernando, R.N.; Eleuteri, B.; Abdelhady, S.; Nussenzweig, A.; Andang, M.; Ernfors, P. Cell cycle restriction by histone $\mathrm{H} 2 \mathrm{AX}$ limits proliferation of adult neural stem cells. Proc. Natl. Acad. Sci. USA 2011, 108, 5837-5842.

35. Rogakou, E.P.; Nieves-Neira, W.; Boon, C.; Pommier, Y.; Bonner, W.M. Initiation of DNA fragmentation during apoptosis induces phosphorylation of H2AX histone at serine 139. J. Biol. Chem. 2000, 275, 9390-9395.

36. Lu, C.; Zhu, F.; Cho, Y.Y.; Tang, F.; Zykova, T.; Ma, W.Y.; Bode, A.M.; Dong, Z. Cell apoptosis: Requirement of H2AX in DNA ladder formation, but not for the activation of caspase-3. Mol. Cell 2006, 23, 121-132.

37. Sluss, H.K.; Davis, R.J. H2AX is a target of the JNK signaling pathway that is required for apoptotic DNA fragmentation. Mol. Cell 2006, 23, 152-153.

38. Wang, W.; Bu, B.; Xie, M.; Zhang, M.; Yu, Z.; Tao, D. Neural cell cycle dysregulation and central nervous system diseases. Prog. Neurobiol. 2009, 89, 1-17.

39. Pospelova, T.V.; Demidenko, Z.N.; Bukereva, E.I.; Pospelov, V.A.; Guskov, A.V.; Blagosklonny, M.V. Pseudo-DNA damage response in senescent cells. Cell Cycle 2009, 8, 4112-4118.

40. Keogh, M.C.; Kim, J.A.; Downey, M.; Fillingham, J.; Chowdhury, D.; Harrison, J.C.; Onishi, M.; Datta, N.; Galicia, S.; Emili, A.; et al. A phosphatase complex that dephosphorylates $\gamma-\mathrm{H} 2 \mathrm{AX}$ regulates DNA damage checkpoint recovery. Nature 2006, 439, 497-501. 
41. Riches, L.C.; Lynch, A.M.; Gooderham, N.J. Early events in the mammalian response to DNA double-strand breaks. Mutagenesis 2008, 23, 331-339.

42. Brooks, P.J. DNA repair in neural cells: Basic science and clinical implications. Mutat. Res. 2002, 509, 93-108.

43. Kruman, I.I. Why do neurons enter the cell cycle? Cell Cycle 2004, 3, 769-773.

44. Fishel, M.L.; Vasko, M.R.; Kelley, M.R. DNA repair in neurons: So if they don't divide what's to repair? Mutat. Res. 2007, 614, 24-36.

45. Nawrocki, A.R.; Scherer, P.E. Keynote review: The adipocyte as a drug discovery target. Drug Discov. Today 2005, 10, 1219-1230.

46. Meulle, A.; Salles, B.; Daviaud, D.; Valet, P.; Muller, C. Positive regulation of DNA double strand break repair activity during differentiation of long life span cells: The example of adipogenesis. PLoS One 2008, 3, e3345.

47. Latella, L.; Lukas, J.; Simone, C.; Puri, P.L.; Bartek, J. Differentiation-induced radioresistance in muscle cells. Mol. Cell. Biol. 2004, 24, 6350-6361.

48. Narciso, L; Fortini, P; Pajalunga, D; Franchitto, A; Liu, P; Degan, P; Frechet, M; Demple, B; Crescenzi, M; Dogliotti, E. Terminally differentiated muscle cells are defective in base excision DNA repair and hypersensitive to oxygen injury. Proc. Natl. Acad. Sci. USA 2007, 104, 17010-17015.

49. Sargeant, T.J.; Day, D.J.; Miller, J.H.; Steel, R.W. Acute in utero morphine exposure slows G2/M phase transition in radial glial and basal progenitor cells in the dorsal telencephalon of the E15.5 embryonic mouse. Eur. J. Neurosci. 2008, 28, 1060-1067.

50. Morin, X.; Jaouen, F.; Durbec, P. Control of planar divisions by the G-protein regulator LGN maintains progenitors in the chick neuroepithelium. Nat. Neurosci. 2007, 10, 1440-1448.

51. Gratzner, H.G. Monoclonal antibody to 5-bromo- and 5-iododeoxyuridine: A new reagent for detection of DNA replication. Science 1982, 218, 474-475.

52. Wang, T.W.; Zhang, H.; Parent, J.M. Retinoic acid regulates postnatal neurogenesis in the murine subventricular zone-olfactory bulb pathway. Development 2005, 132, 2721-2732.

53. Zhao, B.Q.; Wang, S.; Kim, H.Y.; Storrie, H.; Rosen, B.R.; Mooney, D.J.; Wang, X.; Lo, E.H. Role of matrix metalloproteinases in delayed cortical responses after stroke. Nat. Med. 2006, 12, $441-445$.

54. Supnet, C.; Grant, J.; Kong, H.; Westaway, D.; Mayne, M. Amyloid- $\beta-(1-42)$ increases ryanodine receptor-3 expression and function in neurons of TgCRND8 mice. J. Biol. Chem. 2006, 281, 38440-38447.

55. Rass, U.; Ahel, I.; West, S.C. Defective DNA repair and neurodegenerative disease. Cell 2007, 130, 991-1004.

(C) 2014 by the authors; licensee MDPI, Basel, Switzerland. This article is an open access article distributed under the terms and conditions of the Creative Commons Attribution license (http://creativecommons.org/licenses/by/3.0/). 